Acta vet. scand. $1960,1,277-280$.

From the State Veterinary Institute for Virus Research, Lindholm per Kalvehave, Denmark.

\title{
TITRATION OF FOOT-AND-MOUTH DISEASE VIRUS (FMDV) IN CALF KIDNEY CULTURES AND IN MICE
}

By

H. C. Borgen.

Since Bachrach et al. (1), Sellers (2), and Wesslén \& Dinter (3), almost simultaneously proved cytopatic changes in kidney cell cultures inoculated with foot-and-mouth disease virus (FMDV), these cultures have not only found a prominent place within FMD research, but also called forth an ever increasing interest as a valuable aid in the routine investigations connected with type-differentiation and the production and testing of vaccines.

As an illustration of the utility of kidney cell cultures in the routine titration of $\mathrm{FMDV}$ the result is here stated of $2 \times 50$ parallel titrations in kidney cultures and in unweaned mice.

\section{MATERIAL AND METHOD}

Virus: $\mathrm{O}_{2}$-virus samples from modified Frenkel cultures (4, 5).

Mice: Litters of $3-8$ days old young ones of white laboratory mice $(6)$.

Kidney cultures: Primary cultures of kidney cell monolayers in $14 \times 100 \mathrm{~mm}$ tubes with $1 \mathrm{cc}$ of Hanks balanced salt solution (BSS) containing $0.5 \%$ lactalbumin hydrolysate.

Kidney tissue from new-born calves are trypsinised (7), and the disaggregated cells are suspended 1:200 into BSS containing 0.5\% lactalbumin hydrolysate and $5 \%$ active cattle serum. (8). After distribution of the cell suspension into 1 cc per tube, the cultures are incubated as stationary tubes at $37^{\circ} \mathrm{C}$ until the appearance of a cell monolayer (ab. 4 days), upon which the cultures, after change of medium into a serumless one, are incubated as roller tubes until the end of the titration. 
Virus dilutions and inoculations: From each tenfold virus dilution in $\mathrm{m} / 50$ phosphate buffer, $\mathrm{pH} 7.6,8$ tubes and 8 mice are inoculated with $0.1 \mathrm{cc}$ each. Tubes are inoculated by means of 1 cc pipettes graduated into $1 / 100 \mathrm{cc}$, and the mice are inoculated intraperitoneally with 1 cc syringes graduated into 1/10 and mounted with hypodermic needle no. 20 ("Aesculap").

Judgement: On the second day p. i. the kidney cultures are microscopically read with reference to the presence of cytopatic changes which at this time have been complete $-4+-(9)$ in almost all positive cases, and the amounts of cultures with and without degenerations are added up. The mice are attended to daily for 6 days p. i., after which the amounts of live and dead mice respectively are summed up. The titer is computed according to Kärber's method (10), and is given correct to one decimal place by log. $\mathrm{TCD}_{50} / \mathrm{cc}$ and $\mathrm{MLD}_{50} / \mathrm{cc}$ respectively.

\section{RESULTS}

In $2 \times 50$ comparative titrations, executed in kidney cultures and on unweaned mice respectively, representing 41 virus samples, there has, by the application of kidney cultures, been found an average titre of log. 0.5 higher than the one found by mice. The greatest difference of the virus titres determined in kidney cultures and in mice (log. $\mathbf{T C D}_{50} \div \log . \mathrm{MLD}_{50}$ ) have been +1.4 and $\div 0.9$ (table 1 ). By titrating the same virus sample 9 times in kidney cultures a \pm deviation of $\log$. 0.3 has been found, and by means of mice one of log. 0.6 (fig. 1).

Table 1.

Differences of virus titres, determined in kidney cultures and in unweaned mice $\left(\log . \mathrm{TCD}_{50} \div \log . \mathrm{MLD}_{50}\right)$, collected into groups of log. 0.3.

\begin{tabular}{cccc}
\hline Group & $\begin{array}{c}\text { Group- } \\
\text { middle }\end{array}$ & Frequency & $\begin{array}{c}\text { Frequency } \\
\text { in } \%\end{array}$ \\
\hline$\div 1.1-\div 0.9$ & $\div 1.0$ & 1 & 2 \\
$\div 0.8-\div 0.6$ & $\div 0.7$ & 1 & 2 \\
$\div 0.5-\div 0.3$ & $\div 0.4$ & 0 & 0 \\
$\div 0.2-0.0$ & $\div 0.1$ & 2 & 4 \\
$+0.1-+0.3$ & +0.2 & 14 & 28 \\
$+0.4-+0.6$ & +0.5 & 17 & 34 \\
$+0.7-+0.9$ & +0.8 & 8 & 16 \\
$+1.0-+1.2$ & +1.1 & 4 & 8 \\
$+1.3-+1.5$ & +1.4 & 3 & 6 \\
\hline
\end{tabular}




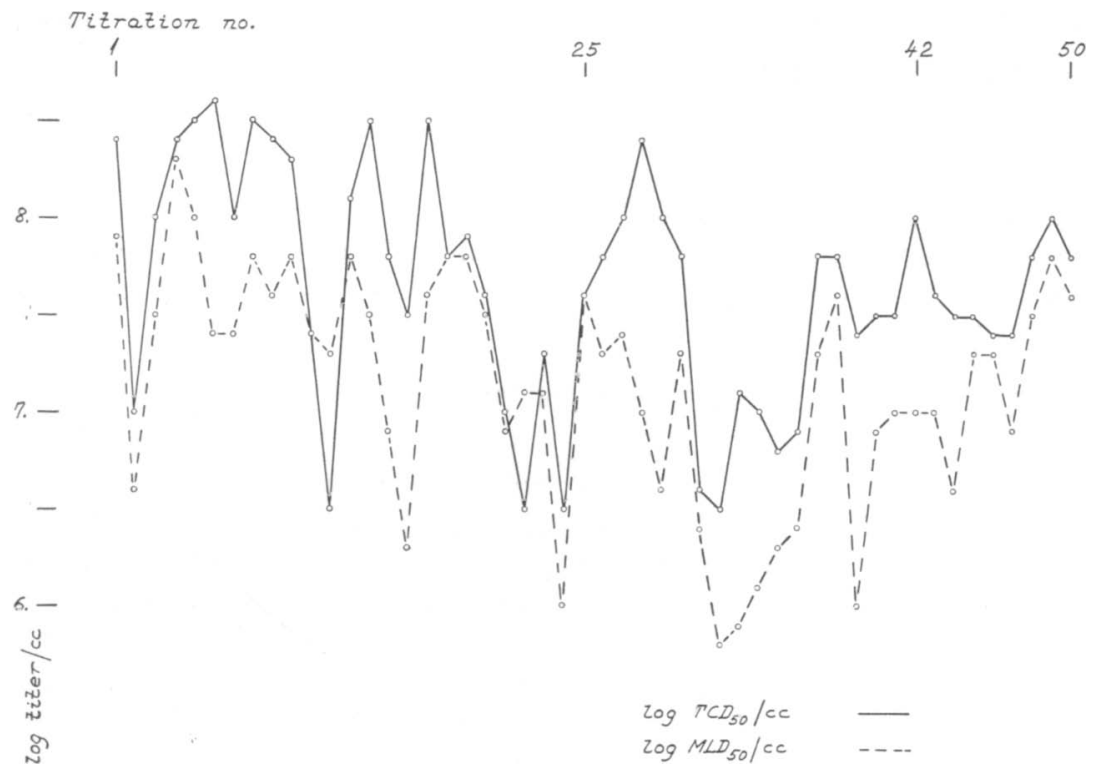

F i g. 1. Comparative titrations executed in kidney cultures and in unweaned mice by means af different virus samples. The titrations numbered 42-50, were executed with the same virus sample. The titres are stated by log. $\mathrm{TCD}_{50} / \mathrm{cc}$ and log. $\mathrm{MLD}_{50} / \mathrm{cc}$.

\section{CONCLUSION}

The stated results show that primary cultures of calf kidney cells fully come up to unweaned mice as regards sensisivity to the applied culture virus, and that the kidney cultures by the inoculation technique routinely applied here have been most suitable for the demonstration of minimal amounts of virus.

\section{REFERENCES}

1. Bachrach, H. L., W. R. Callis \& W. R. Hess.: Science 1955, 122, 1269.

2. Sellers, R. F.: Nature $1955,176,547$.

3. Wesslén, T. \& Z. Dinter: Nord. Vet.-Med. 1956, 8, 795.

4. Willems, R. \& J. Leunen: O. E. E. C. Proj. no. 208, 1957, 73.

5. Gierlфff, B. C. H.: Unpublished data.

6. Skinner, H. H.: Proc. Roy. Soc. Med. 1951, 44, 15.

7. Youngner, J. S.: Proc. Soc. Exp. Biol. Med. 1954, 85, 202.

8. Melnick, J. L.: Diagnostic Procedures for Virus and Rickettsial Diseases. 2. ed. Am. Publ. Health. Ass. N. Y. 1956, 65. 
9. Robbins, F. C., T. H. Weller \& J. F. Enders: J. Imm. 1952, 69, 673.

10. Kärber, G.: Cited from Rhodes \& Van Rhoyen: Textbook of Virology. 2. ed. The Williams and Wilkins Co. Baltimore. 1953,65 .

\section{SUMMARY}

By $2 \times 50$ parallel titrations of foot- and mouth disease virus a log. 0.5 higher titre was found by the application of kidney cultures than by using unweaned mice.

\section{ZUSAMMENFASSUNG}

Titrierung des Maul- und Klauenseuchevirus mit Hilfe von Kalbsnierenkulturen und an Mäusen.

Bei $2 \times 50$ Titrierungen des Maul- und Klauenseuchevirus wurde mit Hilfe von Nierenkulturen ein durchschnittlicher Titer gefunden, der 0.5 log. höher lag als der mit jungen Mäusen erzielte.

\section{SAMMENDRAG}

Titrering af mund-og klovesygevirus ved anvendelse af kalvenyrekulturer og mus.

Ved $2 \times 50$ titreringer af mund-og klovesygevirus er der ved anvendelse af nyrekulturer fundet en gennemsnitlig titer $0.5 \mathrm{log}$. højere end ved anvendelse af museunger.

(Received February 11. 1960). 